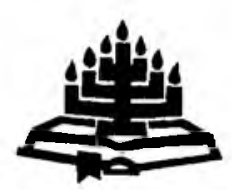

\title{
Sola fide: Die belangrike rol van die geloof in die Christoiogie van Hermann Friedrich Kohlbrugge
}

\author{
A.H. Bogaards, P.J. de Bruyn en J.H. van Wyk \\ Skool vir Kerkwetenskappe \\ Potchefstroomse Universiteit vir $\mathrm{CHO}$ \\ POTCHEFSTROOM \\ E-pos: bogaards@kimberley.co.za
}

\section{Abstract \\ The important role of faith In the Christology of Hermann Friedrich Kohlbrugge}

This article investigates the important role which the concept of sola fide plays in the Christology of Hermann Friedrich Kohlbrugge. Sola fide is decisive not only for the order of salvation but also for the history of salvation as far as the advent and work of Christ are concerned. It is also important to note the determining role ascribed to the grace of God in man's salvation, because man in himself is flesh and totally incapable of saving himself. Faith is not an achievement by man but a free gift of the Spirit of God.

\section{Inleiding}

'n Aspek wat besonder opval in die Christologie van Kohlbrugge', is die prominente plek wat hy aan die geloof gee. Die geloof speel vir hom 'n kardinale rol in die koms van Christus en in sy verlossingswerk.

In hierdie artikel gaan albei aspekte onder oë geneem word: die plek van die geloof in die vleeswording sowel as in die werk van Christus - soos Kohlbrugge dit sien.

1 Hermann Friedrich Kohlbrugge was 'n Nederlands-Duitse teoloog wat geleef het in die vorige eeu (1803-1875) Hy was omstrede onder andere oor sy leer van die heiligmaking (Van Lonkhuijzen, 1905:437-513) en oor aspekte van sy beskouing van die Persoon en werk van Christus (Van Lonkhuijzen, 1905:406-436). 
In 'n tyd waarin subjektivisme die botoon voer, is die siening van Kohlbrugge en die klem wat hy op die sola fide lê besonder aktueel.

\section{Geloof en die wording van Christus}

Kohlbrugge se besondere beskouing oor die plek van die geloof in die koms van Christus moet ook ontleed en beoordeel word.

\subsection{Die Ou Testament as wordingsgeskiedenis van Christus}

\subsubsection{Wording}

In 1844 het 'n besonder belangrike boek uit die pen van Kohlbrugge verskyn: sy Betrachtung über das erste Kapitel des Evangeliums nach Matthäus (Kohibrugge, 1844:1-147). Dit kan as een van die belangrikste bronne vir sy Christologie beskou word, nie alleen van die Nuwe Testament nie, maar ook van die Ou Testament. Die Ou Testament is vir Kohlbrugge, in die lig van Matteus 1, wordingsgeskiedenis, oftewel: geskiedenis van die wording van Christus.

Die woord $\gamma \varepsilon v \varepsilon \varepsilon \varepsilon \omega \varsigma$ in Matteus 1:1 is vir Kohlbrugge in hierdie verband rigtinggewend. Hy (Kohlbrugge, 1844:3) vertaal dit as Werdung. Die geslagsregister waarmee Matteus begin, is daarom nie vir hom 'n boek van die geboorte van Christus nie. Dit is 'n beskrywing hoe Jesus, wat die vlees betref, geword het. Van die geboorte van die Here Jesus is volgens Matteus eers sprake vanaf vers 18 en dit is dan ook die slot en voleinding van Christus se wording.

Dit is vir Kohlbrugge ook nie vreemd dat Matteus die opvolging van drie maal veertien geslagte vanaf Abraham tot Christus die wording van Christus noem nie. In dié verband gebruik Kohlbrugge (1844:3-4) die beeld van 'n boom wat groei totdat dit groot is: al is dit nog klein, is die boom reeds daar, hoewel nie in volkomenheid nie. So was ook Levi reeds daar - in die lendene van Abraham toe Abraham deur Melgisedek geseen is, aldus Kohlbrugge (1844:4).

Kohlbrugge (1844:4) vind verder steun vir sy gedagte in die ïv $\alpha \lambda \eta \rho \omega \theta \hat{n}$, wat hy soos volg parafraseer: “... auf daß erfüllet, völlig geworden sei, was gesagt ist vom Herrn durch den Mund seiner Propheten”. In almal wat in die Ou Testament voorwerpe van die belofte van Christus was - Isak, Israel, Dawid, en so meer was Christus en het die belofte voortdurend ontwikkel. In geeneen van hulle was dit wat hierdie belofte letterlik aangedui het egter volkome aanwesig nie. Dit het eers gebeur toe Christus in die vlees gekom het. "In Ihm sahen sie Alles buchstäblich, wesentlich, völlig; in Ihm das Gesammte, was bei den Einzelnen nur theilweise hervorkam". Graafland (1994:176) begryp die bedoeling van Kohlbrugge goed wanneer hy laasgenoemde se siening ten opsigte van 'n ontwikkelende menswording van Christus in die Ou Testament saamvat in die terme "reeds" en "nog niet". 


\subsubsection{Vleeswording}

Volledigheidshalwe moet kortliks daarop gewys word dat Kohibrugge die wording van Christus as vleeswording sien. Kohlbrugge (1844:91-92) sien die geslagsregister van Matteus 1 as 'n getuienis van hoe die Woord vlees geword het: vlees uit vlees gebore, nie die menslike natuur voor die val nie, maar dié na die val, want dit gaan om vlees wat "nie-Gees" is, wat van God vervreemd is en onder die ban van die verdoemenis lê.

\subsubsection{Geloofswording}

By die $\gamma \varepsilon v \varepsilon \tilde{\varepsilon} \sigma \omega_{\zeta}$ gaan dit geheel en al anders as wat vlees ${ }^{2}$ dit vermoed. Vlees, sê Kohlbrugge (1844:6), soek na 'n heerlikheid wat gesien kan word. Hierdie $\gamma \varepsilon v \varepsilon ́ \sigma \varepsilon \omega \varsigma$ is egter 'n geloofsgenesis. Hier is vleeslike krag van geen waarde nie. $\mathrm{Na}$ die vlees is hier niks anders as hopeloosheid nie.

Enkele voorbeelde om te illustreer wat Kohlbrugge bedoel, word vervolgens aangeraak:

\section{- Abraham}

Abraham ontvang die belofte van die Saad. Maar hoe gaan die belofte in vervulling?

Kohlbrugge (1844:9-10) toon dat dit dwars teen die verwagting van vlees ingaan, want Sara was immers onvrugbaar en dan kom ook nog die Moriageskiedenis. So neem die genesis van Jesus Christus 'n aanvang.

So hat der Vater eine Menge aus einer Fürstin $\kappa \alpha \tau^{-} \varepsilon \xi \circ \chi \eta v$ ein Gelachter gewonnen. Das ist das Aergerniß des Kreuzes - dennoch die hochste Vernunf; grade in solcher Thorheit nach Fleisch Gottes Weisheit, und aus solchem Tode strahlt glanzend hervor seine ewige Treue, seine Herrlichkeit und Wahrheit (Kohlbrugge, 1844:10)

Maar hoe spruit die Saad, Christus, uit Abraham voort? Daarop antwoord Kohlbrugge (1844:18) soos volg: "Beim Glauben Abrahăm an Gott, an seinem Worte: 'also wird dein Same sein'." Die wording van Christus is immers geloofsgenesis vir Kohlbrugge!

\section{- Isak, Rebekka en Jakob}

By die geskiedenis van Isak, Rebekka en Jakob is dit weereens 'n geloofswording wat ter sprake is.

Ná Isak is Jakob die draer van die belofte. Dit lyk egter nie asof hy dit ooit sal ontvang nie, want Isak gee voorkeur aan Esau. Hoe verkry Jakob dan 
uiteindelik wel die belofte? Die antwoord is: deur die geloof van die moeder en die gehoorsaamheid van die seun (Kohlbrugge, 1844:11).

Op hierdie geloof brei Kohlbrugge (1844:11) verder uit: Dit was geloof "in Gestalt einer abscheulichen Lüge, in Gestalt von List und Betrug!" As Isak hardnekkig daaraan vashou om die meerdere te wil seên, breek Rebekka in radeloosheid self die Wet, sodat die Wet nie geskend sal word nie. Sy gryp na lis en leuen, “... sie zeigt sich Mensch, Fleisch, Sünderin, Gläubige, Heilige: sie taucht sich in Sünde hinab, damit nicht sie, sonderen Gottes Wahrheit bleibe, und sich versenkend in ihr Verderben klammert sie sich fest an Gottes Verheißung" (Kohlbrugge, 1844:14).

Waarom teken Kohlbrugge dit so? Om aan te dui dat die belofte van die Saad nie deur en danksy vlees kom nie, maar deur die geloof alleen. Dit gaan teen alle vleeslike verwagting en alle vleeslike aanmatiging in. Dit is suiwer geloofsgenesis.

Hierdie gevolgtrekking is sonder enige twyfel gemik teen diegene wat Kohlbrugge (1844:17) "Frohndiensttreiber" (loondiensdrywers) noem.

\section{- Juda en Tamar}

Kohlbrugge trek dieselfde lyne as in die vorige geskiedenisse wanneer hy die gebeure rondom Juda en Tamar bespreek.

In die geskiedenis van Genesis 38 toon die heiliges dat hulle mense, vlees, sondaars is. Te midde van hulle ongeregtigheid het hulle egter tog nie die bevel van God verontagsaam nie (Kohlbrugge, 1844:18).

Hoe, vra Kohlbrugge (1844:18-19) dan weer, het die Saad, Christus, uit Juda voortgekom? Deurdat Tamar haar gehou het aan die bevel van God en die bevel kom hierop neer: sy is in die stam ingelyf om die stamboom voort te sit en daarom mag sy uit geen ander grond loot en vrug voortgebring het as net uit die wortel, Juda, alleen nie. In die geloof aan daardie belofte het sy gedoen wat sy gedoen het "ohne darauf Acht zu haben, ob es Sünde sei, oder nicht Sünde". Al moes sy ook in die diepste diepte van verlorenheid afdaal - vir haar het dit slegs daarom gegaan: "wenn nur der Befehl Gottes getan wurde".

Hiermee wil Kohlbrugge allermins antinomianisme leer of die sonde van Tamar goedpraat. Inteendeel, hy noem dit wat sy gedoen het sonde en hy noem die heiliges sondaars. Wat hy egter wel by sy lesers wil tuisbring, is hoe Christus geword het: sola fide! Of anders gestel: die mens - wat vlees is kan homself volgens hierdie siening glad nie op die skouer klop nie. Dit is duidelik. 
Aan die einde van hierdie afdeling gee Kohlbrugge (1844:22) weer 'n steek na die heiligheidsdrywers: die kwasimoraliteit en kwasivroomheid van latere tye - diegene wat aanstoot neem aan Tamar se regverdiging deur die geloof alleen - neem aanstoot aan hierdie geskiedenis, maar die troue belyers van God se Naam prys Hom.

\section{- Dawid en Batseba}

In donker kleure teken Kohlbrugge (1844:41) die sondegeskiedenis van Dawid, die man na God se hart: hy wat die Wet van God in sy ingewande het, steur hom nie aan die Woord nie, maar hy pleeg egbreuk, begeer en maak Uria uiteindelik deur goddelose valstrikke dood. Nogeens laat Kohlbrugge sien wat vlees is en doen.

Dit is egter genade wanneer Dawid hom verbryseld buig onder die woorde: "jy is die man!" God se genade, altyd eerste met toenadering, laat hom nie in sy hardnekkigheid volhard nie. Hierdie genade van God buig hom tot diep in die hel en daar vang die genade hom op in die arms van ewige ontferming en dra die verdorwe skaap na die stal. Na die dood van sy kind staan Dawid op en troos sy vrou met die troos waarmee hy getroos is en "die erste Frucht des Glaubens ist der Sohn, den er seinen Herm nennt aus allen Ewigkeiten" (Kohlbrugge, 1844:43).

Die geloof is vir Kohlbrugge geen prestasie van die vlees nie. Dit blyk duidelik uit die voorafgaande. Geloof is 'n skepping van God se genade en die vrug van daardie geloof is die Seun. So word Hy. Dit is alles geloofswording en daartoe lewer vlees geen bydrae nie.

\subsection{Die wording van Christus in die Nuwe Testament: die maagdelike geboorte}

\subsubsection{Die maagdelike geboorte en Maria se geloof}

Wanneer die leer van die maagdelike geboorte en die ontvangenis deur die Heilige Gees by Kohlbrugge onder oë geneem word, val iets dadelik op: die groot plek wat die geloof van Maria daarin inneem.

Die onderwerp kom ter sprake in vrae en antwoorde 179 tot en met 184 van Die Lehre des Heils ${ }^{3}$; dus in ses vrae en antwoorde. In totaal word die woord geloof ses maal in hierdie ses vrae en antwoorde gebruik ${ }^{4}$.

3 Die Lehre des Heils (Kohlbrugge, 1930:1-98) is die kategismus van Kohlbrugge en is 'n belangrike bron om Kohlbrugge se Christologie in die juiste konteks te kan sien. Voortaan sa aanhalings uit Die Lehre des Heils soos volg weergegee word: (LH: v/a 1). "LH" staan vir Die Lehre des Heils, "v" vir vraag, "a" vir antwoord en die getal dui die betrokke vraag/antwoord 
In sy boek oor Matteus 1 staan die geloof in die geskiedenis van die ontvangenis eweneens sentraal5.

\subsubsection{Die voortsettig van 'n denklyn}

Dit is vroeerr in die artikel reeds aangetoon dat Kohlbrugge die wording van Christus in die Ou Testament sien as 'n geloofswording: die belofte van die Saad kom deur die geloof van Abraham, Jakob, Rebekka, Tamar, ensovoorts, en deur die geloof alleen.

Kohlbrugge (1844:104) beskou die maagdelike geboorte as 'n voortsetting van daardie lyn: die geboorte van Isak, Peres, Obed en Salomo was alles "Geburt des Glaubens". Die maagdelike geboorte is ook so, maar van 'n ander aard en op 'n ander wyse. En in sy Kategismus (LH: a 182) skryf Kohlbrugge: die Heilige Gees laat Maria "deur die geloof"6 bevrug raak.

\subsubsection{Ontvangenis ' $n$ menslike realiteit?}

Maar as Kohlbrugge so 'n belangrike plek inruim vir Maria se geloof, word die ontvangenis dan nie te veel van 'n menslike' realiteit, dit wil sê deur mense gerealiseer nie?

Hierdie vraag moet beslis ontkennend beantwoord word, en wel op die volgende gronde:

\section{- Die verset van die vlees}

Vir Kohlbrugge staan dit vas dat die mens nie die outeur van die geloof kan wees nie (De Reuver, 1992:16). Kohibrugge (LH: v/a 293) omskryf geloof as 'n onvoorwaardelike onderwerping aan die mag van die Woord. Juis dit kan die mens egter nie doen nie. Inteendeel, hy is agterdogtig teenoor God en maak Hom tot 'n leuenaar (LH: v/a 16).

aan. As alleen die vraag van belang is, word die aanhaling so weergegee: (LH: v l), en indien net die antwoord relevant is: (LH: a l).

4 Dit is die volgende: "glaubte" (LH: a 180); "geglaubt hast" (LH: a 181); "den Glauben" (LH: a 182); "an diesem Glauben" (LH: a 182); "an Glauben" (LH: v 184); “am Glauben" (LH: a 184).

5 Hy gebruik by die ontvangenis onder andere die volgende terme: "an Glauben" (Kohlbrugge, 1844:113, 139); "beim Glauben" (Kohlbrugge, 1844: 114) en "geglaubt" (Kohlbrugge, 1844 : 113).

6 "an diesem Glauben".

7 In teensteling tot 'n Geestelike realiteit, dit wil sẻ die Heilige Gees, realiscer die ontvangenis, want Hy realiseer die geloof in Maria. 
Dat die mens nie uit homself kan glo nie, sou sekerlik vir Kohlbrugge nie alleen in heilsordelike sin nie, maar ook op heilshistoriese vlak 'n werklikheid gewees het. En inderdaad hoor 'n mens Kohlbrugge (1844:113) oor die geboorteaankondiging deur Gabriël (Luk. 1:35) die volgende sê:

Mit dem Worte des Herrn: 'du hast Gnade bei Gott gefunden' that er ihr das Herz auf; mit der Zusicherung: 'heiliger Geist wird auf dich kommen und Macht eines Allerhöchsten wird dich uberschatten' räumte er das Bedenken des Fleisches weg, und bekräftigte das durch den Zusats: 'nicht wird unmoglich sein bei Gotte irgend ein Ausspruch' (outeurs van artikel se kursivering).

\section{- Die geloof as Geestelike realiteit}

In sy studie oor die geloofsopvatting van Kohlbrugge toon De Reuver (1992:21 22; vgl. Kohlbrugge, 1893:147) aan dat Kohlbrugge die Heilige Gees beskou as die outeur van die geloof. Hy skep die geloofsakte. Hy open die mens se hart.

Dat die Heilige Gees die geloof skep, is vir Kohlbrugge eweneens 'n openbaringshistoriese werklikheid, ' $n$ realiteit in die heilshistorie van die ontvangenis: die Heilige Gees het die geloof in die maagd verwek ( $\mathrm{LH}:$ a 182). Die Heilige Gees het Hom met haar gees verenig om die boodskap aan te hoor, die Woord in die hart op te neem, haar daaraan te onderwerp en om op dié manier "by geloof.' swanger te word. Dit was vug van die Gees (Kohlbrugge, 1844:114; 117). Wat vlees nie kan doen nie, dit doen die Gees: Hy onderwerp Maria aan die Woord. Hierdie onderwerping is vir Kohlbrugge sinoniem met geloof.

\section{- Maria se geloof moet nie losgemaak word van die Woord nie}

Maria het nie swanger geword deur die geloof nie, maar deur haar geloof in die Woord. So sou 'n mens Kohlbrugge se standpunt presies kon weergee, want hy (Kohlbrugge, 1844:113) sê: toe die Here se magswoord deur Gabriël - "jy sal swanger word" - Maria se hart ingedring het, het sy dit eenvoudigweg in 'n eerlike en rein hart opgeneem, haar sonder terughouding aan die Woord onderwerp en toe was sy swanger. "Deur die geloof" het sy dus swanger geword, soos Elisabet dan ook uitroep: "salig is sy wat geglo het"; sy het swanger geword "deur en op die Woord"10 wat sy geglo het (kursivering deur outeurs van hierdie artikel).

Dieselfde verband tussen geloof en Woord lê Kohlbrugge ook in Die Lehre des Heils (LH: v/a 182) wanneer hy sê dat die Heilige Gees Maria aan die hand van

\footnotetext{
8 "beim Glauben".

9 “an Glauben".

10 "durch das Wort und auf dem Worte".
} 
die geloof laat ontvang het toe sy die ewige Woord, dieselfde Woord van die Vader waarin"1 hemel en aarde geskape is, in haar opgeneem het.

Nie die geloof alleen regverdig die mens nie, maar sy geloof in die Woord (vgl. Heidelbergse Kategismus: v/a 61). Dit geld eweneens vir die ontvangenis: deur Maria se geloof in die Woord word sy swanger

Dit is duidelik dat ook die sola Scriptura vir Kohlbrugge nie alleen 'n heilsordelike grootheid is nie, maar ook 'n heilshistoriese een.

\subsubsection{Die plek van die geloof in die wording van Christus}

Vir Kohlbrugge is hierdie aspek 'n besonder belangrike saak. In Matteus 1:25 skryf die evangelis dat Josef Maria nie beken het totdat sy haar eersgeborene gebaar het nie. Daarmee wil Matteus, volgens Kohlbrugge (1844: 135), elke moontlike gedagte in die kiem smoor dat die Seun nie uit die Heilige Gees gegenereer, 'n rein vrug van die geloof is nie. Matteus skryf dit tot beskutting van die waarheid dat God sy Seun gebore laat word het uit 'n vrou; dat die maagd Hom ontvang en gebaar het "aan die hand van die geloof" ("an Glauben"); dat dit nie deur die wil van die vlees of deur die wil van die man was nie (Kohlbrugge, 1844:139).

Die laaste deel van hierdie stelling, naamlik dat dit nie deur die wil van die vlees of deur die wil van die man was nie, onthul waarom dit vir Kohlbrugge so belangrik is: daarmee word vlees geheel en al uitgeskakel in die koms van die Saad. Hy kom enkel en alleen as vrug van die Gees: aan die hand van die geloof?

\subsubsection{Hierdie geloof van Maria is noodsaakllk}

Kohlbrugge stel dit onomwonde: Christus kon Hom as Here uit die hemel op geen ander wyse in die mens se toestand bevind of hierbenede kom as juis deur die geloof nie - die geloof wat al middel is waardeur alles rein en heilig kan bly (LH: v/a 184; vgl. Kohlbrugge, 1844:116).

Die geloof van Maria het vir hom alles te make met die onbevlekte ontvangenis: daardeur alleen bly alles rein en heilig. Dit is deur die geloof alleen en as sodanig hoegenaamd geen prestasie van die mens nie.

\subsection{Samevattend}

By hierdie vleeswording van Christus lewer vlees - dit wil sê wat vlees doen, die werke van die mens - geen insette nie. Die wording van Christus is vir Kohlbrugge pure geloofswording en daardie geloof is 'n genadewonder van God. 
Of om Kohlbrugge se opvatting in meer moderne teologiese terme te klee: openbaringshistories gesien, is die koms of wording van Christus 'n geloofsgenesis. Die "deur die geloof alleen" speel nie net in die heilsordelike 'n alleenbeslissende rol nie. In die heilshistoriese is geloof eweneens alleenbepalend. Of soos Noordmans (1990:20) dit stel: "De ladder, waarlangs Christus indaalt in de wereld, is het geloof der bijbelheiligen." Daarby moet dan gevoeg word dat hierdie leer vir Kohlbrugge nie mensemaaksel, nie produk van die vlees is nie, maar skeppingswerk van God se genade.

Kohlbrugge lewer hier baie beslis 'n heel besondere - 'n nuwe - insig. Hy oortuig ook met sy Skrifbewyse dat sy gedagte nie on-Bybels is nie. Hierdie gedagte kan 'n unieke trek in sy Christologie genoem word.

\section{Geloof en die werk van Christus}

Die belangrike rol wat die geloof in die werk van Christus speel, en Kohlbrugge se siening daaroor, word vervolgens nagegaan..

\subsection{Die geloof van Christus en sy kruisiging}

\subsubsection{Ongeloot, ongehoorsaamheid, nie by/in die Woord bly nie}

Wanneer Kohlbrugge dit oor sonde en die sondeval van die mens het, duik drie uitdrukkings telkens weer op: ongeloof, ongehoorsaamheid en nie in of by die Woord bly nie. Ten opsigte van laasgenoemde praat hy ook daarvan dat die mens uit die Woord uitgegaan het.

Kohlbrugge (1884:184; vgl. 1992a:344) beskryf die sonde as die mens se afval van die lewende God op grond van vermetelheid en wantroue jeens God. Ook setel die sonde in die mens se oorgawe aan die duiwel om sy wil te doen, in plaas daarvan om te bly by die Woord wat uit die mond van God uitgegaan het.

Volgens Kohlbrugge (1889:25-26; vgl. 1992b:414) was die doel12 van die skepping van die mens dat hy aan God die gehoorsaamheid sou bring wat hy aan Hom as Skepper verskuldig was. Tot sulke priesters het God die mens gemaak. Die mens het egter die wil van God verontagsaam - hy het ongehoorsaam, sondaar, oortreder geword.

God is in sy hoogwaardigheid gekrenk deur ongehoorsaamheid en ongeloof en die feit dat geen mens in die Woord gebly het nie (Kohlbrugge, 1981:192; 1898b:265). Adam het uit die Woord uitgegaan, dit nie gehoorsaam nie, en daarmee was hy die beeld van God kwyt (Kohlbrugge, 1993:27).

\footnotetext{
12 "Endzweck". Die woord "doel" sal voortaan meermale gebruik word. Dit is ook 'n herhaaldelik terugkerende term
} 


\subsubsection{Die weg ferug: geloof, gehoorsaamheid, bly by die Woord}

Vir Kohlbrugge staan dit vas dat daar vir die mens net een weg terug is en dit is die pad van geloof, gehoorsaamheid en deur te bly by die Woord.

Dié gehoorsaamheid moes weer aan God bewys word, as Hy God en Koning wou bly en as die mens verlos wou word van die bande van die duisternis en die hel (Kohlbrugge, 1889:26; vgl. 1992b:414).

God het die geloof aan sy Woord gewil (Kohlbnugge, 1992d:426). Die geloof alleen is die enigste, hoogste en beste goeie werk. Geloof is die enigste goeie werk van alle goeie werke wat die hoë God kan behaag (Kohlbrugge, 1849:60; vgl. 1937:73).

By God gaan dit om die beginsel van volkome gehoorsaamheid tot in die dood, die beginsel van die heeltemal volmaakte geloof aan en vertroue op sy Woord, die beginsel van die mees onvoorwaardelike onderwerping aan sy geregtigheid en dit absoluut vrywillig. Alleen dan sal God weer sy vriendelike aangesig oor sy skepsel laat skyn en hom in genade aanneem (Kohlbrugge, 1898a:22; 1992d: 202).

\subsubsection{Die mens kan nie die weg na God baan nie}

Ewe vas as wat dit egter vir Kohlbrugge staan dat daar net een weg terug is, ewe oortuig is hy daarvan dat die mens nie daardie weg kan baan nie.

Dit is vir die mens wat van God afvallig geword het, onmoontlik om aan God die verskuldigde gehoorsaamheid te bring, want sedert sy afval glo hy die duiwel (Kohlbrugge, 1993:31). Dit is vir die mens heeltemal onmoontlik om in die Woord te bly (LH: v/a 37). Kohlbrugge (LH: v/a 293) omskryf geloof as 'n onvoorwaardelike onderwerping aan die mag van God se Woord. Dit is egter juis hierdie onderwerping wat die mens wat van God vervreem is nie kan regkry nie. Die mens het uit die Woord van God uitgetree - 'n toestand wat vir Kohlbrugge sinoniem is met die uittree uit die beeld van God en die verlies van God self (De Reuver, 1992:11, vgl. ook Kohlbrugge, 1839:45; 1932:47-48). Die naam wat die gevalle en ontadelde mens nou dra, is vlees. Hy dra nie alleen die naam nie, maar hy het dit geword: vlees in al sy denke en dade, heeltemal weg van God af, heeltemal weg uit die element van die Woord; so het al sy dade sonde geword, hyself 'n vyand van God en God vir hom 'n vyand (De Reuver, 1992:11; vgl. Kohlbrugge, 1992c:347). Hierdie "vlees" is tot heelwat in staat, maar nie tot geloof nie (De Reuver, 1992:12; vgl. Kohlbrugge, 1839:71 en 1932:71).

\subsubsection{God skep die weg deur sy Seun}

Waar dit vir die mens onmoontlik is om die weg terug te baan, daar doen God dit en God doen dit deur sy Seun. 
Weer val 'n trio woorde of uitdrukkings op: die Here Jesus gehoorsaam, bly by of in die Woord en glo. Hierdie drietal sal voortaan telkens opduik.

In vraag $212(\mathrm{LH})$ vra Kohlbrugge hoe God deur die dood van sy Seun die Wet gehandhaaf het. Daarop antwoord hy soos volg: "Hy, hoewel Seun, het uit dit wat Hy gely het, gehoorsaamheid geleer; Hy was gehoorsaam gewees tot die dood toe; daarmee het God die gehoorsaamheid wat ons aan die Wet verskuldig was weer herstel - Heb. 5:8; Fil. 2:8" (vertaling - outeurs van die artikel).

Reeds vroeër in hierdie artikel is gemeld hoe belangrik Kohlbrugge die geloof ag: dit is die vernaamste goeie werk en God het die geloof aan sy Woord gewil. Op hierdie gedagte borduur Kohlbrugge (1992d:426) voort wanneer hy sê dat in hierdie wil die mens se versoening, begenadiging en saligheid lê. Christus het die doen van hierdie wil op Hom geneem en heerlik voleindig. Dit is vir Kohlbrugge die betekenis van die uitdrukking dat Christus die Leidsman en Voleinder van die geloof is (Heb. 12:2).

Elders verklaar Kohlbrugge (1895:27; 1992b:359) die volgende: "Er, das ewige Wort, blieb in dem Worte; er stellte den Glauben an Gott wieder her. So vollbrachte er das ewige Gesetz, so erwarb er die ewige Gerechtigkeit, so versöhntte er Gott" (kursivering - Kohlbrugge).

Dit is duidelik dat die geloof van Christus vir Kohlbrugge daarin bestaan dat Hy gehoorsaam was aan die Woord en dat Hy daarin gebly het. Terwyl Adam uit die Woord uitgegaan het, het Christus volhard by die Woord. Hy het geen oomblik, selfs nie in sy gedagtes, daarvan afgewyk nie. Verder sê Kohlbrugge (1993:27) "Dat was het geloof van onze Heere. Alzó werd aan Gods eer genoeggedaan. God heeft door Christus' bloed Zijn eer weder" (kursivering - outeurs van hierdie artikel). Elders stel Kohlbrugge (1884:97; vgl. 1992a:237) dit nog duideliker wanneer hy sê dat Christus God geglo het dat Hy God se raad tot saligheid juis sou uitvoer indien $\mathrm{Hy}$ in die woorde van die Vader bly, wat die swaarste lyding en die dood aan die kruis vir Hom voorspel (Joh. 12:27; Matt. 26:42, 54). "So ist es also durch Glauben Jesu Christi, da er sein Blut zur Erde hat ausgießen lassen, $\mathrm{da} B$ Gott wieder in seinem Rechte und wir gerecht geworden sind, gerecht geworden sind in seinem Blut" (kursivering: Kohlbrugge). Die geloof van Christus is vir Kohlbrugge sekerlik nie 'n abstrakte iets wat in die lug hang nie, maar dit vind konkreet en prakties gestalte in die feit dat Christus deur die stort van sy bloed gehoorsaam was aan en gebly het in die Woord.

Die geloof van die Here Jesus was 'n geloof deur die teenstrydige heen. Hoewel in die gelowige se plek in die wanhopigste toestand, het $\mathrm{Hy}$ daardeur heen sy geloof behou en sy vertroue op God bly stel. Ofskoon ' $n$ wurm en geen man nie, het Hy nogtans in die dae van sy vlees die wete gehandhaaf: "Hy daarbo is my Vader en Ek is sy Seun." So het Hy die sege behaal (Kohlbrugge, 1889:15; vgl. 
1992b:402-403). Hy het, ofskoon Hy niks anders as die teenstrydige, "das Wiederspiel", gesien het nie, nooit die geloof aan sy Vader prysgegee nie, nooit die geloof prysgegee dat Hy die Seun is nie. In al sy onuitspreeklike angs, in al die smarte en verskrikkings wat $\mathrm{Hy}$ in die dae van sy vlees gely het, in die uiterste verlatenheid het Hy herstel wat die mens in die paradys bederf het en nog daagliks bederf (Kohlbrugge, 1889:21; vgl. 1992b: 409-410).

Aan die kruis is Christus se eerste woord "Vader" en as Hy in die kake van die dood val, roep Hy weer: "Vader". Hy handhaaf Hom as Seun in weerwil van die hellevaart en glo van die Vader dat Hy sy Vader is en bly, alhoewel die Satan Hom sal kerker in die angs, in die gevangenis van die dood en van die hel. Sy laaste uitroep - 'n aanhaling uit Psalm 31 - is 'n skreeu van geloofsversekerdheid: "Mein Vater is der zuverlässige Bewahrer meines Geistes; in seinen Händen geht er unverletzt durch alle Gewalt des Obersten der Macht der Finsternis hindurch, und ist bei ihm in Ruhe und Ehre" (Kohlbrugge, 1981:218; vgl. 1898b: 304). En dan vervolg Kohlbrugge (1981:218; vgl. 1898b:304-305):

Wer begreift diesen Glauben, der so nichts in eigener Hand halt, der nichts vernimmt, nichts sieht, nichts vermag, keine Antwort vom Himmel empfängt, - und mit den Worten des 31. Psalms sich selbst und seinen Geist übergibt in die Hände des Vaters, den er nicht sieht, dessen Stimme er nicht vernimmt. - Und wie er geglaubt, so geschieht's.

In die lig hiervan verklaar Kohlbrugge (1981:217; vgl. 1898b:302) dat "dieses Ablegen seines Lebens die letzte und grôßte Tat seines Glaubens gewesen ist" (kursivering: outeurs van hierdie artikel).

In sy laaste oomblikke buig Christus sy hoof en sterf (Joh. 19:30). In 'n preek oor hierdie gebeurtenis herinner Kohlbnugge (1981:219; vgl. 1898b:305-306) sy hoorders aan die beweging wat Simson gemaak het voordat hy die kerk ${ }^{13}$ van die afgod Dagon bo hom ineen laat stort en op die vorste en die hele volk laat val het: "En hy het hom met krag gebuig" (Rigt. 16:30). So het Christus Hom ook in sy sterwe met krag gebuig en daarmee dui Hy aan dat Hy "mit seinem Glauben" alle kerke $^{14}$ en alle afgode wat op die hel gebou is, ineen laat stort het. Ja, Hy het die ganse ryk van die duiwel, van die duisternis en van die dood vernietig, juis toe Hy sy liggaam wat aan die kruis gebreek is, in die mag van die dood oorgegee het.

Dit is duidelik dat die geloof by Kohlbrugge nie alleen in die koms van Christus 'n rol speel nie, maar ook in sy werk hier op aarde. Die geloof is in die heilsgeskiedenis van Christus se verlossingswerk van kardinale belang. Dit is 'n geloof wat vergestalting vind in die gehoorsaamheid tot die dood, die dood van

\footnotetext{
13 Kohlbrugge praat self hier van "Kirche"

14 "Kirchen".
} 
A.H. Bogaards, P.J. de Bruyn \& J.H. van Wyk

die kruis. So is die verlossing ook heilshistories deur die geloof alleen - sola fide: deur die geloof alleen, omdat Christus in die Woord alleen bly en Hom deur die Woord alleen laat lei. Daarom is die verlossing eweneens deur die Woord alleen - sola Scriptura!

Loos (1948:143) interpreteer Kohlbrugge se bedoeling as dat die mens nie regverdig word voor God deur sy eie geloof nie. Dié geloof is immers sondig en vleeslik. Die mens word geregverdig deur die geloof van Jesus Christus, dit is "door het geloof, waarmede Hij, die mensch was in onze plaats, zich aan Gods beloften vastgehouden heeft". Met hierdie gedagte kan ten volle saamgestem word as daarmee bedoel word dat die mens die regverdiging nie deur sy geloof verdien nie, maar dat sy geloof alleen die instrument is om dit toe te eien (vgl. H.K. v/a 61). Daarteenoor is die geloof van Christus die verdienende oorsaak.

Die gedagte van die geloof van Christus is nie vreemd aan die Skrif en die gereformeerde dogmatiek nie. Bavinck (1976:297) verwys ook daarna, hoewel hy daarop wys dat die geloof van Christus verskil van die geloof van die mens na die sondeval: die geloof van die gevalle mens is 'n steun op God se genade en barmhartigheid, terwyl die geloof by Christus niks anders was as 'n vasklem aan die Woord en die beloftes van God, 'n vashou aan die Onsienlike nie. Bavinck verwys in dié verband ook na verskillende Skrifgedeeltes (Matt. 27:46; Heb. $2: 17,18 ; 3: 2)$.

\subsection{Die geloof von Christus en sy opstanding}

Soos by die kruisiging speel die geloof ook ten opsigte van hierdie aspek vir Kohlbrugge 'n belangrike rol.

In die Woord word soms gesê dat Christus "opgestaan" het (vgl. onder andere Matt. 17:9, 23; Luk. 24:6; Joh. 21:14). Ander kere weer lui dit dat Hy "opgewek" is (vgl. onder andere Hand. 3:26; Rom. 4:24 en 10:9) of dat Hy "lewend gemaak" is ( 1 Pet. 3:18). Soms word die opstanding dus gesien as 'n daad van Christus (vgl. onder andere Matt. 17:9, 23; Luk. 24:6; Joh. 21:14) en ander kere weer as 'n daad van die Vader (vgl. onder andere Hand. 3:26; Rom. 4:24 en 10:9) of as daad van die Gees (1 Pet. 3:18).

Kohlbrugge is ook bewus van hierdie onderskeid (LH: v/a 241). Die "opstaan" van Christus het vir hom alles te make met Christus se geloof: Christus het opgestaan in die mag van die gebod, wat Hy daartoe van die Vader ontvang het Deur sy geloof aan daardie gebod het Hy die lewe weer opgeneem, en die Vader het opgetree volgens hierdie geloof. In antwoord 241 (LH) is 'n duidelike weerklank van Johannes 10:18, waar Jesus van sy lewe sê: "Niemand neem dit van My af nie, maar Ek lê dit uit Myself af. Ek het mag om dit af te lê en Ek het mag om dit weer te neem. Hierdie gebod het Ek van my Vader ontvang." 
Elders kom Kohlbrugge (1971:155) op hierdie teks terug waar hy sê:

En daar Hij op dit gebod ziet, weet Hij, dat de dood niet machtiger is dan Zijns Vaders wil en gebod Daarom spreekt de Heere, kunt gijlieden mij vrij doden, ik sterf toch niet, want ik heb het eeuwige leven in mij en dat blijft. Dus: $l k$ zal niet sterven maar leven.

\subsection{Samevattend}

Deur die geloof alleen kon Christus die geregtigheid wat voor God geld, aanbring en deur sy geloof aan God se gebod het $\mathrm{Hy}$ die lewe weer geneem en is $\mathrm{Hy}$ opgewek deur die Vader. Dit is dus sola fide!

\section{Samevatting}

Die geloof is vir Kohibrugge beslissend- nie alleen in die heilsorde nie, maar ook in die heilshistorie van die koms en die werk van Christus.

God vervul sy groot belofte oor die Saad in die heilsgeskiedenis deur die geloof van die heiliges onder die Ou Verbond en deur Maria se geloof in die Woord word die belofte, die ontvangenis van Christus, gerealiseer.

Deur die geloof alleen kon Christus die geregtigheid wat voor God geld, aanbring, en deur sy geloof aan God se gebod het Hy die lewe weer geneem en opgestaan.

Die heil is dus vir Kohlbrugge sola fide!

Kohlbrugge het 'n groot stryd gehad teen die subjektivisme15 van sy tyd. Juis daarin lê Kohlbrugge se aktualiteit vir die hede, want wie meen dat die subjektivisme vandag dood is, moet maar net gaan kyk na die opbloei van die Pinksterbewegings. Jonker (1983:238) noem dit selfs die kulminasiepunt van die subjektivisme. Pelagianisme, semi-Pelagianisme en Arminianisme kom egter nie net voor by die Pinkstergroepe nie. Onlangs het 'n boek verskyn waarin radiopreke van 1994 tot 1995 (uitgesaai deur die SABC) ontleed word (Cilliers, 1996: 1-145). Die skrywer (Cilliers, 1996:16-17) kom tot die bevinding dat wettisisme in daardie preke eerder die reel as die uitsondering is. Vir alle subjektivistiese strominge sê Kohlbrugge: die heil is nie alleen heilsordelik nie, maar selfs heilshistories sola fide.

15 Diegene wat ook die mens 'n aandeel wil gee in sy verlossing en nie die heil uitsluitlik in die hande van Christus laat nie. 


\section{Bibliografie16}

BAVINCK, H. 1976. Gereformeerde Dogmatiek. Derde deel. Zesde onveranderde druk Kampen : Kok

CILLIERS, J. 1996. Die uitwissing van God op die kansel: ontstellende bevindings oor SuidAfrikaanse prediking. Kaapstad : Lux Verbi

DE REUVER, A. 1992. Bedelen bij de Bron. Kohlbnugge's geloofsopvatting vergeleken met Reformatic en Nadere Reformatie. Zoetermeer : Boekencentrum.

GRAAFLAND, C. 1994. De Christusprediking van Kohlbrugge. Ecclesia, 85:171-176, 179181.

JONKER, W.D. 1983. Die Gees van Christus. Pretoria : NG Kerkboekhandel

KOHLBRUGGE, H.F. 1839. Das siebente Kapitel des Briefes Pauli an die Römer in ausführlicher Umschreibung. Von Hermann Friedrich Kohlbragge ${ }^{17}$, doctor der Theologie Elberfeld : Sam. Lucas.

KOHLBRUGGE, H.F. 1844. Betrachtung über das erste Kapitel des Evangeliums nach Matthäus. Als Handschrift gedruckt. Elberfeld : Sam Lucas.

KOHLBRUGGE, H.F. 1849. Sieben Predigten über den Propheten Jona. Gehalten im Sommer 1848 von H.F. Kohlbrügge, Doctor der Theologie, Pastor der niederländisch-reformirten Gemeine in Elberfeld. Elberfeld : Lowenstein.

KOHLBRUGGE, H.F. 1884. Zwanzig Predigten im Jahre 1846 gehalten. Elberfeld Kaufmann.

KOHLBRUGGE, H.F. 1889. Licht und Recht. Predigten von Herm. Fried. Kohlbrügge, Dr. Theol., weil. Pastor der niederländisch-reformirten Gemeine zu Elberfeld. Drittes Heft. Elberfeld : Verlag der niederland.-reform. Gemeine.

KOHLBRUGGE, H.F. 1893. Uit den schat der kerk. Den leer van den Heiligen Geest. Amsterdamse Zondagsblad tot Getuigenis der Waarheid, 6(21):145-148, Mei 21.

KOHLBRUGGE, H.F. 1895. Licht und Recht. Predigten von Herm. Fried. Kohlbrügge, dr. Theol., weil. Pastor der niederländisch-reformirten Gemeine zu Elberfeld. Achtes Heft. Elberfeld : Verlag der niederlănd-reform. Gemeine.

KOHLBRUGGE, H.F. 1898a. Licht und Recht. Predigten von Herm. Fried. Kohlbrügge, dr. Theol., weil. Pastor der niederlandisch-reformirten Gemeine zu Elberfeld. Elftes Heft. Elberfeld : Verlag der niederländ-reform. Gemeine.

KOHLBRUGGE, H.F. 1898b. [1876.] Lijdenspreken gehouden in de jaren 1847, 1848 en 1849, door dr. H.F. Kohlbrügge, in leven predikant bij de Nederlandsch-Gereformeerde Gemeente te Elberfeld Uit het Hoogduitsch Tweede herziene druk. Amsterdam : Scheffer

KOHLBRUGGE, H.F. 1930 [1903.] Die Lehre des Heils in Frage und Antworten. Wuppertal-Elberfeld : Verlag der niederland.-reform. Gemeine in Wuppertal-Elberfeld.

KOHLBRUGGE, H.F. 1932. Het zevenden hoofstuk van Paulus' brief aan de Romeinen in uitvoerige omschrijving door dr. H.F. Kohlbrügge. Opnieuw uit het Hoogduitsch vertaald. Amsterdam : Vereeniging tot uitgave van Gereformeerde Geschriften.

16 Wanneer 'n datum in vierkantige hakies agter die datum in die bibliografie gegee word, verwys dit na die datum van die eerste druk van die boek.

17 Ofskoon die skryfwyse Kohlbrugge geyk geraak het, was die oorspronklike skryfwyse wel met 'n deelteken (d.w.s. Kohlbrugge) 
KOHLBRUGGE, H.F. 1937. Zeven preken over den profeet Jona. Gehouden in den zomer van het jaar 1848 door H.F. Kohlbrugge, doctor theol. en predikant van de Nederlandsche Gereformeerde Gemeente te Elberfeld. Nieuwe vertaling uit het Hoogduitsch door ds. B. Gijzel, Ned. Herv. Pred. te Amsterdam. Amsterdam Vereeniging tot uitgave van Gereformeerde Geschriften.

KOHLBRUGGE, H.F. 1971. Schriftverklaringen door dr. H.F. Kohlbrügge In leven predikant bij de Nederlands-Gereformeerde Gemeente te Elberfeld. XVII. Berkel : Protestantse Periodieke Pers

KOHLBRUGGE, H.F. 1981. Passionspredigten. Wuppertal : Verlag und Schriftenmission der Evangelischen Gesellschaft für Deutschland.

KOHLBRUGGE, H.F. 1992a. Twaalf twaalfallen leerredenen in nagenoeg chronologische volgorde. Derde, ongewijzigde druk van de nieuwe en van aantekeningen voorziene uitgave (1910-1917) Eerste en tweede twaalftal gehouden in 1833 en 1846 . Houten : Den Hertog.

KOHLBRUGGE, H.F. 1992b. Twaalf twaalftallen leerredenen in nagenoeg chronologische volgorde. Derde, ongewijzigde druk van de nieuwe en van aantekeningen voorziene uitgave (1910-1917). Vijfde en zesde twaalftal gehouden in 1847 en 1848 . Houten : Den Hertog.

KOHLBRUGGE, H.F. 1992c. Twaalf twaalftallen leerredenen in nagenoeg chronologische volgorde. Derde, ongewijzigde druk van de nieuwe en van aantekeningen voorziene uitgave (1910-1917) Sewende en achtste twaalftal gehouden in 1848 en 1849 Houten : Den Hertog.

KOHLBRUGGE, H.F. 1992d. Twaalf twaalftallen leerredenen in nagenoeg chronologische volgorde. Derde, ongewijzigde druk van de nieuwe en van aantekeningen voorziene uitgave (1910-1917). Elfde en twaalfde twaalfal gehouden in 1850 en 1851. Houten Den Hertog

KOHLBRUGGE, H.F 1993. Schriftverklaringen. Hebreeen 1-6. Houten : Den Hertog.

LOOS, J. 1948. De theologie van Kohlbrugge. Amsterdam : Uitgeversmaatschappij Holland.

NOORDMANS, O. 1990. De betekenis van Kohlbrugge voor de theologie van onze tijd. (In Noordmans, O Geestelijke perspectieven Amsterdam : Paris. p. 15-36.)

VAN LONKHUIJZEN, J. 1905. H.F Kohlbrugge, zijn prediking in de lijst van zijne tijd. Wageningen : Naamloze Vennootschap Drukkerij "Vada". 